\title{
Growth performance of weaner rabbits fed graded levels of plantain leaf
} Enyenihi $^{1 \alpha}$, G. E., Inyang ${ }^{1}$, U. A. and Ime, J. E.

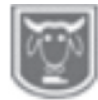

${ }^{\prime}$ Department of Animal Science, University of Uyo, Nigeria

${ }^{\text {a}}$ Corresponding author: gloryenyenihi@yahoo.com; idarakang72@gmail.com; +2348028259884

\section{Abstract}

The potentials of non-conventional resources are great as they play an important role in alleviating the problem of cost and competition of conventional feed sources for livestock and poultry in Nigeria. This study aimed at investigating the growth performance of weaner rabbits fed graded levels of plantain leaf $(P L)$. Thirty mixed bred rabbits aged 6-8 weeks old with an average weight of $0.70 \pm 0.02 \mathrm{~kg}$ were randomly allotted to five experimental treatments of three replicates each in a completely randomized design. Treatments consisted of $T 1$ - concentrate alone (control), T2 - T5 had $25 \mathrm{~g}, 50 \mathrm{~g}, 75 \mathrm{~g}$ and $100 \mathrm{~g}$ of PL respectively. Proximate composition of the feed were carried out while initial weight, final weight, feed intake, feed conversion and weight gain were measured. Results revealed that the crude protein and crude fibre contents of the concentrate and PL recorded $19.30 \%$ and $9.97 \% \mathrm{vs}$ $0.98 \%$ and $8.11 \%$ respectively. Initially weight ranged from $0.65 \mathrm{~kg}-0.76 \mathrm{~kg}$. Rabbits on T2 recorded the least final weight $(0.98 \mathrm{~kg})$ which was similar to those on $T 4(1.05 \mathrm{~kg})$ and $T 3$ (1.10kg) but lower $(P<0.05)$ than those on $T 5$ and $T 1$ (1.32 $\mathrm{kg}$ and $1.38 \mathrm{~kg}$ respectively). Rabbits on $T 5$ recorded the highest intake of PL $(83.72 \mathrm{~g} / \mathrm{d})$ while those on T2 had the least $(21.04 \mathrm{~g} / \mathrm{d})$. Weight gain was highest $(0.68 \mathrm{~kg})$, for rabbits on T1 but least for those on T2 $(0.23$ $\mathrm{kg}$ ). The feed conversion ratio ranged from 4.65 (T1) to 14.85 (T4). Rabbits were able to tolerate the plantain leaf meal up to $100 \mathrm{~g}$. In addition, rabbits on $100 \mathrm{~g} /$ day plantain leaf performed comparably with those on control.

Keywords: Growth, Rabbits, Plantain leaf, concentrate, feed intake

\section{Introduction}

An Animal that is deprived of proper nutrition cannot give its best; hence, adequate feeding in terms of its quality and quantity becomes imperative. Rabbits have attracted interest as an economical source of animal protein (Egbo et al., 2001). Topmost in the attributes promoting the production of rabbits includes high fecundity, growth rate and the ability to utilize forages and turn out of low cost/high quality proteins (Biobaku and Dosumo, 2003; Odimba, 2006). Egbo et al. (2001) reported that rabbits are efficient converters of feed to meat and utilize up to $30 \%$ fibre as against $10 \%$ by most poultry species. Forages can act as basal diets of rabbits (Linga and Lukefahr, 2000) although there is improvement in performance of rabbits fed concentrate and forage compared to feeding forage or pellets alone (Biobaku and Dosumo, 2003; Taiwo et al., 2005). Some conventional forages used for feeding rabbits include Panicum maximum, Pureria phaseloides, Centrosema pubesceus, Mucuna cochinchinensis (Aduku and Olukosi, 1990) just to mention a few. Most of these forages are found in abundance in arable farm environments but getting them during the dry season can be a problem thus the investigation on the use of plantain leaves which can withstand the dry season. While the plantain fruit is a valuable foodstuff for human consumption, the waste part of it can be fed to livestock. The fruit wastes (peels), stems and leaves can be utilized as energy sources for livestock and in particular during the dry season when there are feed shortages. However, there is dearth of information on the use of plantain wastes in 


\section{Growth performance of weaner rabbits fed graded levels of plantain leaf}

rabbit production. Therefore, this paper examines the performance of rabbits fed graded levels of plantain leaves in terms of growth.

\section{Materials and methods Experimental site}

The experiment was conducted at the rabbitry unit of the University of Uyo Teaching and Research Farm.

\section{Experimental material and diet}

Rabbits were bought from a rabbit farmer at Uyo, Akwa Ibom State. The plantain leaves were harvested from household farms, school farm and fed fresh to the rabbits. A concentrate diet was formulated as shown in Table 1. The five experimental diets consisted of the following:

Treatment 1: $60 \mathrm{~g}$ concentrates alone

Treatment 2: $30 \mathrm{~g}$ concentrate plus $25 \mathrm{~g}$ plantain leaf

Treatment 3: $30 \mathrm{~g}$ concentrate plus $50 \mathrm{~g}$ plantain leaf

Treatment 4: $30 \mathrm{~g}$ concentrate plus $75 \mathrm{~g}$ plantain leaf

Treatment 5: $30 \mathrm{~g}$ concentrate plus $100 \mathrm{~g}$ plantain leaf

Table 1: Composition of concentrate diet

\begin{tabular}{ll}
\hline Ingredients & $\mathbf{\%}$ \\
\hline Maize & 58.00 \\
Soya bean meal & 10.00 \\
Wheat offal & 10.00 \\
Fish meal & 7.00 \\
Bone meal & 10.00 \\
Palm kernel cake & 1.50 \\
Salt & 0.50 \\
Premix & 2.50 \\
L -Lysine & 0.25 \\
DL - Methionine & 0.25 \\
Total & $\mathbf{1 0 0 . 0 0}$ \\
\hline
\end{tabular}

\section{Experimental animals and design}

Thirty mixed bred rabbits of both sexes with ages ranging from 6-8 weeks old were randomly divided into five treatment groups with each replicated three times of two rabbits each. The experiment lasted eight weeks after two weeks of feed and housing acclimatization prior to the data collection. The rabbits were housed under intensive system, using wooden and metallic hutches which were covered with mesh that permitted inspection, ventilation and dropping of faeces on the pan underneath the hutch. In each hutch were feeding and watering troughs which were made of concrete. The sanitation of the rabbit house was maintained. Prophylactic medications were administered against prevalent rabbit infections. The rabbits were fed concentrate in the morning at 8am and the fresh plantain leaf (chopped to bit sizes) in the evening. For those on control, they were split fed $30 \mathrm{~g}$ in the morning and $30 \mathrm{~g}$ in the evening.

\section{Data collection}

Before commencement of the growth performance trial, the rabbits were weighed to obtain uniform initial weights across treatments. Thereafter, weekly weights were measured to determine the weights gains. Feed intake was determined by obtaining the difference between the quantity of feed and forage offered and the left over feed offered to the animals. Data generated were used to calculate the body weight changes and feed conversion ratio.

\section{Data analysis and proximate analysis}

Data were subjected to analysis of variance according to Snedecor and Cochran (1978), where analysis of variance indicated 


\section{Enyenih, Inyang and Ime}

significant treatment effects; means were compared using Duncan's New Multiple Range Test as outlined by Obi (1990). Proximate composition of the diets/treatments was determined by the procedure described by AOAC (1995).

\section{Results and discussion}

Table 2 shows the proximate composition
(\%) of the concentrate diet and fresh plantain leaf on dry matter basis. The dry matter of the concentrate $(92.74 \%)$ is higher than that of the plantain leaf $(36.85 \%)$. The crude protein of the concentrate $(19.30 \%)$ was also higher than that of the plantain leaf. The crude fibre value of the plantain leaf $(8.11 \%)$ is comparable with that of the concentrate diet $(9.97 \%)$.

Table 2: Proximate composition of concentrate diet and fresh plantain leaf

\begin{tabular}{lll}
\hline Parameters & Concentrate & Plantain leaf \\
\hline Dry matter (\%) & 92.74 & 36.85 \\
Crude Protein (\%) & 19.30 & 10.98 \\
Crude Fat (\%) & 11.11 & 1.84 \\
Crude Fibre (\%) & 9.97 & 8.11 \\
Ash (\%) & 18.18 & 13.55 \\
Nitrogen free extract (\%) & 41.44 & 65.52 \\
Energy (cal/kg) & 3429.50 & 699.60 \\
\hline
\end{tabular}

The dry matter content of plantain leaf $(19.27 \%)$ as cited by Aduku and Olukosi (1990) is lower than the value $(36.85 \%)$ reported here. The crude protein $(10.98 \%)$, crude fat $(1.84 \%)$, ash $(13.55 \%)$ is comparable with $18.21 \% \mathrm{CP}, 1.42 \%$ (fat) and $13.72 \%$ ash cited by Aduku and Olukosi (1990). The dry matter (92.74\%) and crude protein contents $(19.30 \%)$ of the concentrate reported in this study compared with $90.13 \%$ and $18.12 \%$ reported by Oloruntola et al. (2015) consisting of maize, wheat offal, groundnut cake, bone meal, premix and table salt. From Table 2, it appears that the concentrate diet possesses a higher nutritive value compared to the plantain leaf. Table 3 shows the growth performance characteristics of weaner rabbits.

Table 3: Growth performance characteristics of rabbits

\begin{tabular}{lllllll}
\hline & T1 & T2 & T3 & T4 & T5 & SEM \\
\hline Initial weight $(\mathrm{kg})$ & 0.70 & 0.75 & 0.70 & 0.70 & 0.65 & 0.11 \\
Final weight $(\mathrm{kg})$ & $1.38^{\mathrm{a}}$ & $0.98^{\mathrm{c}}$ & $1.10^{\mathrm{bc}}$ & $1.50 \mathrm{c}$ & $1.32^{\mathrm{ab}}$ & 0.08 \\
Weight gain $(\mathrm{kg})$ & $0.68^{\mathrm{a}}$ & $0.23^{\mathrm{c}}$ & $0.40^{\mathrm{ab}}$ & $0.35^{\mathrm{ab}}$ & $0.67^{\mathrm{a}}$ & 0.05 \\
Daily weight gain (g/d) & $12.14^{\mathrm{a}}$ & $4.11^{\mathrm{c}}$ & $7.14^{\mathrm{ab}}$ & $6.25^{\mathrm{ab}}$ & $11.96^{\mathrm{a}}$ & 0.02 \\
Dry matter intake (g/d) & $55.91^{\mathrm{d}}$ & $50.38^{\mathrm{e}}$ & $72.53^{\mathrm{c}}$ & $92.80^{\mathrm{b}}$ & $113.10^{\mathrm{a}}$ & 12.04 \\
Feed conversion ratio & $4.65^{\mathrm{e}}$ & $12.26^{\mathrm{b}}$ & $10.16^{\mathrm{c}}$ & $14.85^{\mathrm{a}}$ & $9.46^{\mathrm{d}}$ & 2.10 \\
Mortality & 16.67 & 16.67 & 16.67 & 0.00 & 33.33 & \\
\hline
\end{tabular}

abc means on the same row with different superscripts are significantly different $(p<0.05)$

The final weight for rabbits on T1 $(1.38 \mathrm{~kg})$ was comparable to those on T3 $(1.32 \mathrm{~kg}$ respectively) but higher $(\mathrm{p}<0.05)$ than those of T3, T2 and T4 $(1.10 \mathrm{~kg}, 0.98 \mathrm{~kg}$ and $1.05 \mathrm{~kg}$ ). This noticeable trend can be seen in weight gain and daily weight gain. The difference in value of final weight gain of rabbits in treatments 1,2 and 4 indicates differences in nutritive value and intakes. The altered effect observed in dry matter intake may be as a result of the feed given. Apart from those on T1, other rabbits had two sets of feeds and this enhanced their intakes. However, rabbits on concentrate recorded a higher intake $(\mathrm{p}<0.05)$ compared to those on T2 $(55.91 \mathrm{~g} / \mathrm{d}$ vs 


\section{Growth performance of weaner rabbits fed graded levels of plantain leaf}

$50.38 \mathrm{~g} / \mathrm{d})$. The reason for this might be that rabbits on $\mathrm{T} 2$ were not too familiar with the PL in their diet. The differences in feed intake could also be attributed to taste and fibre content of the feed (Omole et al., 2008) also acceptability. The average daily weight gain in this study is comparable to $7.14-12.03 \mathrm{~g} / \mathrm{d}$ reported by Ekpenyong (1984); Oloruntola et al. (2015) in weaner rabbits fed concentrates combined with forages. The final weight reported in this study also compared with $1.07 \mathrm{~kg}-1.34 \mathrm{~kg}$ by Oloruntola et al. (2015). Banana/plantain leaves cannot meet animal requirements alone, therefore supplementation with nitrogen and energy or its incorporation in a diet containing other feedstuffs and forages are suggested (Ffoulkes and Preston, 1978). Rabbits could be fed up to $40 \%$ without negative effects on growth, feed intake and physiology while $60 \%$ inclusion rate reduced dry matter intake (Rohilla and Bujarbaruah, 2000). The feed conversion ratio (FCR) is an index of the efficiency of converting unit feed into unit weight gain. There was no trend in the values for FCR. However, rabbits on T1 recorded the least $(p<0.05)$ value of 4.65 while those on T4 had the highest (14.85). Rabbits on T1 had the best value followed by those on T5 (4.65 vs 9.46). The values reported here were higher than those obtained by Oloruntola $e t$ al. (2015) which ranged between 3.62 and 4.55. This may be attributed to the feed, genetic makeup of the rabbits and environment.

\section{Conclusion}

This study has shown that fresh plantain leaves can be incorporated up to $100 \mathrm{~g} / \mathrm{day}$ in diets of weaner rabbits since it promoted growth performance without any side effects.

\section{References}

Aduku, A. O. and Olukosi, J. O. 1990. Rabbit management in the tropics: production, processing, utilization, marketing future prospects. Abuja, Nigeria. Living Books Services.

AOAC 1995. Officials method of analysis. $16^{\text {th }}$ Edition. Association of Analytical Chemist. Washington DC.

Biobaku, W. O. and Dosunmu, E. O. 2003. Growth response of rabbits fed graded levels of processed and dehulled sunflower seed. Nigerian Journal of Animal Production 30(2): 179-184.

Egbo, M. L., Doma, U. D. and Lacdaks, A. B. 2001. Management in Bauchi metropolis. Proceedings of $26^{\text {th }}$ Animal Conference of Nigerian society for Animal Production (NSAP). $18^{\text {th }}-21^{\text {st }}$ March, 2001. ABU, Zaria, Nigeria. Pp 160-162.

Ekpenyong, T. E. 1984. Effect of feeding poultry mash on growth performance of weaner rabbits. Journal of Applied Rabbit Research 7: 144-146.

FFoulkes, D. and Preston, T. R. 1978. The banana plant as cattle feed: digestibility and voluntary intake of different proportions of leaf and pseudostem. Tropical Animal Protection 3(2): 1-6.

Obi, I. U. 1990. Statistical method of detecting differences between treatment means. $2^{\text {nd }}$ edition. Snap Press, Enugu Nigeria. Pp. 25-85.

Odimba, N. E. 2006. Influence of forage legumes (Centrosema pubescens, Calopogonium phaseolides) on the semen characteristics and testicular dimensions of rabbits. B. Agric thesis. College of Animal Science and Animal Health, 
Michael Okpara University of Agriculture, Umudike, Nigeria.

Oloruntola, O. D., Daramola, O. T. and Omoniyi, S. O. 2015. Effect of forages on performances carcass cuts and haematological profile of weaner rabbits. Arch. Zootech. 64(245): 87-92).

Omole, A. J., Ajasin, F.O., Oluokun, J. A, Obi, O. O. and Owosibo, A. 2008. Performance characteristics of weaved rabbits fed plantain peel as replacement for maize (review). Emerald group publishing Ltd.

Rohilla, P. P. and Bujarbaruah, K. M. 2000. Effect of banana leaves feeding on growth of rabbits. Indian Vet. J. 72(2):902-903.

Linga, S. S. and Lukefahr, D. S. 2000. Feeding alfalfa hay with molasses blocks or crumbles to growing rabbits fryers. Livestock Res. Rural Dev. 12:1-2.
Snedecor, G. W. and Cochran, W. G. 1978. statistical methods. $6^{\text {th }}$ edition, Lowa State University Press, Lowa.

Taiwo, A. A., Adejuigbe, A. D., Adebowale, E. A., Oshotan, J. S. and David, O. O. 2005. Performance and nutrient digestibility of weaned rabbits fed forages supplemented with concentrate. Nigerian Journal of Animal Production. 32(1): 74-78.

Received: $19^{\text {th }}$ March, 2019

Accepted: 26 ${ }^{\text {th }}$ July, 2019 